\title{
Populations of Wild and Semi-Cultivated Tomatoes in Aguascalientes, Mexico
}

\author{
Alfonso de Luna Jiménez*, José Luis Arredondo Figueroa, José de Jesús Luna Ruíz, Irene de los \\ Ángeles Barriga Sosa and Jorge Martínez de Lara \\ Center of Agricultural Sciences, Mexico
}

*Corresponding author: Alfonso de Luna Jiménez, Center of Agricultural Sciences, Mexico

\section{ARTICLE INFO}

Received: 彗 June 11, 2019

Published: 崫 June 21, 2019

Citation: Alfonso de Luna Jiménez, José Luis Arredondo Figueroa, José de Jesús Luna Ruíz, Irene de los Ángeles Barriga Sosa, Jorge Martínez de Lara. Populations of Wild and Semi-Cultivated Tomatoes in Aguascalientes, Mexico. Biomed J Sci \& Tech Res 19(1)-2019. BJSTR. MS.ID.003237.
ABSTRACT

During 2015 and 2016 in the CA of UAA, 5 semi-cultivated lines and 2 wild $S$. Lycopersicum were agronomically characterized. In the market were acquired the semicultivated and the wild were collected in San Tadeo Calvillo and El Llano Aguascalientes. The fruit was extracted from the seed, germinated in Styrofoam tray. The substrate consisted of a mixture of peat-most + coconut fiber + solarizado cattle manure + soil, as pots were used black bags of $25 \mathrm{~cm}$ wide by $33 \mathrm{~cm}$ high, a completely randomized design was used, the treatments were the genotypes with 10 Repetitions, each flowerpot was an experimental unit. When the plant was about $10 \mathrm{~cm}$ high, were transplanted and started counting number of days to floral button (DBF), Days to start flowering (DIF), counted the number of composite leaves (NHC), height to the first flower cluster (ARF), number of branches (NR), number of leaves per plant (NHP) and number of leaflets per sheet (NFH).

Of each plant was taken a fruit, it was weighed (GR) in electronic scale, with Vernier was measured its equatorial diameter (DE), polar diameter (DP), the firmness of the fruit was measured, it split in half and it was counted the number of locules, also it was qualified to the fruits by its form , considering the categories: flattened, round (plum shape), elongated round (pear shape) and elongated cylindrical. Finally, all the fruits were harvested per plant and weighed to obtain the yield. The plant height was statistically the same in the treatments, in number of branches were found notable differences, resulting that the wild genotypes, branched more from the base, pointing out that they show a creeping habit. The variable height to the first floral cluster was higher in the Ceresa genotype, following the Salcero, with respect to the number of floral clusters (NRF), the wild genotypes surpassed the semi-cultivated genotypes, an important agronomic characteristic because It indicates high potential of yield, which is strengthened with the results obtained with the variables number of flowers per plant (NFP) and number of fruits per plant (NFrP). In the evaluation of the fruits, the higher weight corresponded to the genotypes semi-cultivated and the lower to the wild ones due to the size of the fruit, in the variables, equatorial diameter (OF) and polar diameter (DP) highlighted the genotypes semi-cultivated compared to The wild, in terms of the number of locules the zebra genotype exceeds the rest of the genotypes, while in firmness of the fruit all the genotypes showed to be intermediate.

\section{Introduction}

Currently in Mexico, 112,000 hectares of S. Lycopersicum tomatoes are cultivated with a production of 2.8 million tons FAO [1] that are widely distributed in the Mexican Republic Sánchez et al. [2] However, there is little documentation of genetic potential and its use either directly or as a source of genes for improvement. As a result of its evolution, it has developed characteristics that have allowed it to survive in adverse conditions, as well as to be resistant to pests and diseases Pérez et al. [3]; Tolerant to extreme temperatures, droughts and unfavourable edaphic conditions Hoyt [4]. For example, the largest populations of wild tomatoes have been collected at altitudes between 0 and 1200 m.a.s.l. Vargas et al. [3]. The importance of knowing about the genetic diversity 
between cultivated and wild lines is fundamental to contribute to the biotechnology development of crops and the maintenance of germplasm of the species, therefore, it was considered the objective of evaluating agronomically samples of wild tomatoes and semidomesticated, collected in Aguascalientes, México (Table 1).

Table 1: Variables measured in plant and fruits.

\begin{tabular}{|c|c|c|c|c|c|c|c|c|c|c|}
\hline & \multicolumn{9}{|c|}{ Variables en planta } & \multicolumn{4}{c|}{ Variables en frutos } \\
\hline Tratamiento & AP & NR & APRF & NRF & NFP & NFrP & P/F (g) & DE & DP & NL \\
\hline Cebra & $24.0 \mathrm{~b}$ & $6.2 \mathrm{c}$ & $13.4 \mathrm{~d}$ & $4.8 \mathrm{~d}$ & $15.4 \mathrm{c}$ & $0.2 \mathrm{~b}$ & $6.987 \mathrm{ab}$ & $2.09 \mathrm{a}$ & $2.45 \mathrm{a}$ & $2.2 \mathrm{a}$ \\
\hline Cereza & $50.2 \mathrm{a}$ & $11.6 \mathrm{~b}$ & $32.5 \mathrm{a}$ & $11.6 \mathrm{c}$ & $34.5 \mathrm{~b}$ & $1.4 \mathrm{~b}$ & $0.695 \mathrm{~b}$ & $0.36 \mathrm{~b}$ & $0.39 \mathrm{~b}$ & $0 \mathrm{~b}$ \\
\hline Uva alargado & $41.8 \mathrm{a}$ & $8.8 \mathrm{bc}$ & $14.6 \mathrm{~d}$ & $11.5 \mathrm{c}$ & $44.9 \mathrm{~b}$ & $7.5 \mathrm{a}$ & $4.011 \mathrm{ab}$ & $1.02 \mathrm{ab}$ & $1.41 \mathrm{ab}$ & $1.3 \mathrm{ab}$ \\
\hline $\begin{array}{c}\text { Silvestre } \\
\text { Calvillo }\end{array}$ & $42.6 \mathrm{a}$ & $22.1 \mathrm{a}$ & $16.0 \mathrm{~cd}$ & $25.2 \mathrm{a}$ & $85.4 \mathrm{a}$ & $11.3 \mathrm{a}$ & $0.551 \mathrm{~b}$ & $0.81 \mathrm{ab}$ & $0.71 \mathrm{~b}$ & $1.4 \mathrm{ab}$ \\
\hline $\begin{array}{c}\text { Silvestre el } \\
\text { Llano }\end{array}$ & $43.6 \mathrm{a}$ & $21.2 \mathrm{a}$ & $15.0 \mathrm{~cd}$ & $21.3 \mathrm{~b}$ & $75.9 \mathrm{a}$ & $10.3 \mathrm{a}$ & $0.648 \mathrm{~b}$ & $0.84 \mathrm{ab}$ & $0.82 \mathrm{~b}$ & $1.2 \mathrm{ab}$ \\
\hline Salcero & $44.6 \mathrm{a}$ & $6.9 \mathrm{c}$ & $26.0 \mathrm{ab}$ & $8.3 \mathrm{~cd}$ & $28.4 \mathrm{bc}$ & $10.4 \mathrm{a}$ & $13.132 \mathrm{a}$ & $1.62 \mathrm{ab}$ & $1.37 \mathrm{ab}$ & $1.2 \mathrm{ab}$ \\
\hline Uva Redondo & $46.4 \mathrm{a}$ & $9 \mathrm{bc}$ & $21.2 \mathrm{bc}$ & $9.8 \mathrm{c}$ & $32.3 \mathrm{bc}$ & $0.2 \mathrm{~b}$ & $3.646 \mathrm{ab}$ & $1.2 \mathrm{ab}$ & $1.37 \mathrm{ab}$ & $1.5 \mathrm{ab}$ \\
\hline Anova & $* *$ & $* *$ & $* *$ & $* *$ & $* *$ & $* *$ & $* *$ & $* *$ & $*$ & $*$ \\
\hline
\end{tabular}

1= Cebra, 2=Cereza, 3= Uva alargado, 4=Silvestre Calvillo, 5=Silvestre el Llano, 6=Salsero, 7= Uva redondo. AP= Altura de planta, $\mathrm{cm}$; NR=Número de ramas; APFR=Altura al primer racimo floral, $\mathrm{cm}$; NRF=Número de racimos florales, NFP=Número de flores por planta, $\mathrm{NFrP}=$ Número de frutos por planta, $\mathrm{PF}=$ Peso de fruto, g; DE=Diámetro ecuatorial, $\mathrm{cm}$; DP=Diámetro polar, $\mathrm{cm}$ y NL= Número de lóculos. Las medias que no comparten una letra son significativamente diferentes. Tukey, 0.05.

\section{Materials and Methods}

Fruits of wild plants were collected in San Tadeo and El Llano, Aguascalientes, also in the market were acquired the semicultivated collections: elongated grape, round grape, zebra, cherry Chico and Salsero. The fruits were extracted manually by the seed, to do so, they were macerated in a sieve with fine mesh and to remove the pulp were washed with water, dried in the shade and the pulp adhered to the seed by friction separated from it and the dust was eliminated by air Ation. The seeds obtained were germinated in styrofoam tray of 200 cavities, was used as peat-most substrate. Subsequently, black bags were filled $25 \mathrm{~cm}$ wide by $33 \mathrm{~cm}$ high, with the substrate prepared with peat-most + coconut fiber + bovine manure Solarizado + soil, leaving $5 \mathrm{~cm}$ of upper edge to stop the irrigation water, were laid out at the tables of the Greenhouse in lots of 10 pots per collection, each pot was a repetition. When the plant was about $10 \mathrm{~cm}$ high, the most vigorous and healthy appearance were selected, they were removed with rootball and transplanted to the pots, where irrigation was applied frequently of 3 times per week.

The experimental Unit (EU) was a flowerpot, each pot contained one plant, in the plant were measured variables: plant height (AP), number of branches (NR), height to the first floral cluster (APRF), number of floral clusters (NRF), Number of flowers (NFP) and number of Fruits (NFrP). At harvest, the variables were measured: weight per fruit (g), equatorial diameter (DE), polar diameter (DP) and number of locules (NL).

In the previous table it is shown that with the exception of Zebra, the plant height was statistically the same in all the populations, but in the number of branches there were notable differences, resulting that the wild genotypes branched more from the base, indicating a habit of creeping growth.

The height at the first floral cluster differs ( $p<0.01$ ) among the genotypes (Tukey, 0.05). Number of floral clusters showed differences ( $p<0.01$ ) between treatments, wild genotypes significantly outperformed the semi-cultivated, indicating high yield potential. The number of flowers per plant showed differences ( $p<0.01$ ) between the treatments and in the comparison test of means (Tukey, 0.05) the wild genotypes Calvillo and El Llano are indicated with a greater number of flowers. The number of fruits per plant showed differences $(p<0.01)$ between the treatments and the comparison test of means (Tukey, 0.05), I indicate with greater fruiting the wild genotypes Calvillo and Llano, in addition to Salsero and Uva Redondo. The weight of fruits per plant showed differences $(p<0.01)$ between the treatments and the comparison test of means (Tukey, 0.05), highlighting the fruits of greater weight corresponding to the Salsero genotype. In the Zebra genotype, the variables: equatorial diameter of the fruit, polar diameter and number of locules showed differences in the analysis of variance $(p<0.05)$ as well as in the comparison test of means (Tukey, 0.05).

\section{Conclusion}

The variables showed significant differences $(\mathrm{p}<0.05)$, which indicates phenotypic diversity of the materials evaluated. In number of flower clusters and number of fruits, the wild genotypes surpassed the semi-cultivated genotypes, which indicates high yield potential. For future work it is suggested to increase the number of collections and complement with the genetic characterization. 


\section{References}

1. (2010) FAO, Faostat. Área cosechada, producción y rendimiento de tomate.

2. Sánchez PP, K Oyama, J Núñez F, J Formoni, S Hernández V, et al. (2006) Sources of resistance to whitefly (Bemisia spp.) in wild populations of Solanum lycopersicum var. cerasiforme (Dunal) Spooner G.J. Anderson et R.K. Jansen in Northwestern México. Genetic Resources and Crop Evolution 53(4): 711-719.

3. Pérez, GM, F Márquez S, A Peña L (1997) Mejoramiento genético de hortalizas. Universidad Autónoma Chapingo. Chapingo, México pp. 149181.

\section{ISSN: 2574-1241}

DOI: 10.26717/BJSTR.2019.19.003237

Alfonso de Luna Jiménez. Biomed J Sci \& Tech Res

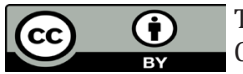

his work is licensed under Creative Commons Attribution 4.0 License

Submission Link: https://biomedres.us/submit-manuscript.php
4. Hoyt E (1992) Conservando los parientes silvestres de las plantas cultivadas. Addison-Wesley Iberoamericana. Delaware, Estados Unidos de América. Traducción: Enrique Forero p. 52.

5. Vargas CD, E Rodríguez G, JJ Sánchez G, Sn Montes H, A Ruiz C, et al. (2005) Adaptación climática de Lycopersicum en el occidente de México. Avances en la Investigación Científica en el CUCBA. Universidad de Guadalajara. México 207-210.

$\begin{array}{ll}\text { BIOMEDICAL } & \text { Assets of Publishing with us } \\ \text { RESEARCHES } & \text { - Global archiving of articles } \\ \text { ISSN: } 2574-1241 & \text { - Immediate, unrestricted online access } \\ \end{array}$

